\title{
The effect of immigration on some population genetic parameters of the Hungarian Hucul population
}

\author{
Enikő Somogyvári - János Posta - Sándor Mihók \\ University of Debrecen Faculty of Agricultural and Food Dciences and Environmental Management, \\ Institute of Animal Science, Biotechnology and Nature Conservatioon, Debrecen \\ somogyvari.eniko@agr.unideb.hu
}

\begin{abstract}
SUMMARY
Population genetic indicators of the Hungarian Hucul population were calculated taking also into account the effect of imported horses. The birth year of the examined 3002 individuals ranged between 1871-2015. The last year involved in the examination was 2015, when the research was conducted on the stock under stud book control. The calculations on the population were made using the statistic indicators in the Endog programme, with and without the imported Polish horses. Figures were depicted using R software. Number of offspring of the Polish individuals was presented in tables; the distribution of the offspring per stud and per mare family, as well as the Nei's genetic distance, were presented graphically.
\end{abstract}

Keywords: Hucul Horses, genetic diversity, impact of imported animals

\section{ÖSSZEFOGLALÁS}

Populációgenetikai méröszámokat számítottunk, a magyarországi hucul lófajta állományában, vizsgálva az import lovak hatását azok alakulására. 1871 és 2015 között született 3002 egyedet vizsgáltuk. Referencia populáció a 2015-ben törzskönyvi ellenörzésben tartott állomány volt. Az Endog programban lévö statisztikai méröszámokra készitettük el a számításokat a populációra, importált lengyel lovakkal, valamint nélkülük. A grafikus ábrázoláshoz az R programot használtuk. A lengyel egyedek ivadékainak számait táblázatosan, a törzsenkénti, valamint kancacsaládokénti ivadékszám eloszlást és a Nei-féle genetikai távolságot grafikusan ábrázoltuk.

Kulcsszavak: hucul, genetikai diverzitás, importok hatása

\section{INTRODUCTION}

Based on pedigree data the impact of seven individuals (purchased in Poland) was examined on the structure of the Hungarian Hucul horse population. Immigration has on important role in endangered species therefore such research is justified and may help in developing breeding programmes and mating schemes. It helps in setting the direction and determining the extent of the adjustment; may serve as guidance as regards the nature of the immigration and the practical mating systems and thereby help in sustaining the diversity of the populations. The aim of our examinations was to evaluate the genetic structure of the Hungarian Hucul population based on pedigree data, by applying population genetic methods, especially considering the effect of imported horses modifying genetic structure.

The impact of imports was examined by Lámfalusy (2012) who studied the effect of 14 imported stallions on inbreeding in the case of Lipizzaner horses. Bartolomé et al. (2011) conducted research on Spanish sports horses and Koenena et al. (2004) studied sports horses from various countries examining the same effect.

Zabek et al. (2005) examined the Nei's genetic distance between Bilgoraj, Malopolski and Thoroughbred. Marletta et al. (2006) estimated the distance of 7 Spanish and 3 Italian local horse breeds and populations from a Spanish Thoroughbred; Khanshour et al. (2013) studied among others the Nei's genetic distance in an Arabian horse population. Plante et al. (2007) examined the genetic diversity of Feral Horses in Sable Island. Vostrá-Vydrová et al. (2016) published a study on the genetic diversity of and the Nei's genetic distance between two colour variations of Old Kladruber horses.

\section{MATERIALS AND METHODS}

In our study we analysed the Hungarian Hucul population (2015 being the last year whose stud book records were used). The birth year of the examined 3002 individuals ranged between 1871-2015. Our reference population horses involved in the study, was a stock of 318 individuals, under stud book control in the year 2015. We examined how the use of the Polish stallions 3139 Polan (Pol), 4122 Goral Parter (Pol), 3883 Goral Ploskor (Pol), 5137 Hroby Bryf (Pol), 4677 Hroby Grad (Pol), 3921 Pietrosu Jadeit (Pol) and the mare Hroby Wilia (Pol) in the breeding influenced certain population genetic indicators of the whole population and of the reference stock. In the course of the examination we calculated Nei's genetic distance using the Endog software (Gutiérrez and Goyache 2005) and were depicted using R software. Evaluation of the number of offspring was evaluated and graphically presented applying MS Excel.

Genetic relations between lines and families are characterised by the Nei's distance (Nei 1987). The Nei's distance between lines can be determined by the formula

$$
D^{i j}=D_{i j}-\left[\left(D_{i i}+D_{j j}\right) / 2\right]=\left[\left(f_{i i}+f_{j j}\right) / 2\right]-f_{i j}
$$

where $D_{i j}$ is the Nei's minimum genetic distance between subpopulations $\mathrm{i}$ and $\mathrm{j}$ and $\mathrm{f}_{\mathrm{ij}}$ is the lineage coefficient per pair between the lines $i$ and $j$. 
Number of progeny was evaluated considering the number of born progeny of a given breeding animal and the number of progeny kept for breeding. Besides the offspring distribution of the reference stock and mare families were also examined.

\section{RESULTS AND DISCUSSION}

\section{Offspring size evaluation}

The number of born offspring of the seven Polish imported horses as well as, from these, the individuals involved in the breeding are summarised in Table 1. The highest number of offspring, 99, came from 3139 Polan (Pol), almost half of which, 47, were involved in the breeding, producing 155 grandsons and granddaughters altogether. The impact of 3139 Polan is apparent in the fourth generation today. We can thus see to how great an extent this stallion has been used and what a major impact it has had on the population structure. The second largest offspring size was born from 4677 Hroby Grad (Pol): 70 individuals altogether. Only a quarter of his offspring were involved in the breeding, making it less powerful in the breeding than Polan. The number of his grandsons and granddaughters is only 37 . It must be considered at the same time that, compared to 3139 Polan (Pol), 4677 Hroby Grad (Pol) has not spent as much time in the breeding yet as he got involved in the breeding much later; through his first offspring he currently exercises his influence in the third generation. Nevertheless his exploitation in the breeding can be considered significant. The exploitation in the breeding of 4122 Goral Parter (Pol) and his son 3883 Goral Ploskor (Pol) is medium. The exploitation of 3921 Pietrosu Jadeit (Pol), 5137 Hroby Bryf (Pol) and Hroby Wilia (Pol) in the breeding is insignificant if compared to the above stallions. However, 5137 Hroby Bryf (Pol) and Hroby Wilia (Pol) are two younger horses whose offspring were born after 2010, and thus their impact on the genetic structure may grow later on. It must be also considered that Hroby Wilia is a mare, while Hroby Bryf spent considerable time in performance analysis and has accordingly and inevitably lower impact than the other stallions on the genetic structure of the population.

The number of offspring of the seven Polish individuals involved in the breeding

\begin{tabular}{lcccccccc}
\hline \multicolumn{1}{c}{ Individual } & $\begin{array}{c}\text { Year of } \\
\text { birth }\end{array}$ & $\begin{array}{c}1^{\text {st }} \text { generation (born/ } \\
\text { used in breeding) }\end{array}$ & $\begin{array}{c}2^{\text {nd }} \text { generation (born/ } \\
\text { used in breeding) }\end{array}$ & $\begin{array}{c}3^{\text {rd }} \text { generation (born/ } \\
\text { used in breeding) }\end{array}$ & $\begin{array}{c}4^{\text {th }} \text { generation (born/ } \\
\text { used in breeding) }\end{array}$ \\
\hline 3139 Polan (Pol) & 1984 & 99 & 47 & 155 & 33 & 58 & 4 & 5 \\
4677 Hroby Grad (Pol) & 2002 & 70 & 17 & 37 & 2 & 3 & 0 & - \\
3883 Goral Ploskor (Pol) & 1997 & 30 & 2 & 4 & 0 & - & - & - \\
4122 Goral Parter (Pol) & 1982 & 26 & 12 & 54 & 6 & 10 & 0 & - \\
5137 Hroby Bryf (Pol) & 2005 & 16 & 0 & - & - & - & - & - \\
3921 Pietrosu Jadeit (Pol) & 1977 & 5 & 0 & - & - & - & - \\
Hroby Wilia (Pol) & 2002 & 2 & 1 & 1 & 0 & - & - \\
\hline
\end{tabular}

The changes in offspring size in the reference stock as an effect of the Polish horses, projected to studs and mare families (Figures 1-4) were also examined. First we evaluated the changes made on stallion studs.

Figures 1-2 illustrate the effects of the seven Polish individuals on the stallion studs. The first offspring of 3139 Polan $(\mathrm{Pol})$, born in Poland in 1984, were born in 1998 and had a contribution $12 \%$ of the whole population. It is very important to note that it was through him that the stud Polan was introduced in Hungary. The stud Goral is quite frequent in its breed; it is at the same time the oldest breed with several genealogical lines. As an effect of the immigration from Poland, the contribution the stud Goral grew by 5 percent. The individuals responsible for the growth were 3883 Goral Ploskor (Pol), 4122 Goral Parter (Pol) and their offspring. Logically the shares of other studs decreased to some extent.

Figures 3-4 illustrate the distribution of families as an effect of the immigration. As an effect of the seven individuals, the presence of the mare families 1 Panca, Árvácska, Aspiráns, 5 Plosca further increased, while the contribution 11 Rotunda, 4 Kitca, 86 Deremoxa and 882 Gelnica simultaneously decreased. The contribution certain mare families, such as 17 Aglia, 2 Lucina, 3 Tatarca, Bulkovina, 70 Sekacka and 825
Agla, hardly changed at all. There were no changes in the case of 12 Sarata, Wrona, Wydra and 90 Machocha.

Figure 1: The offspring distribution of the reference stock per stud

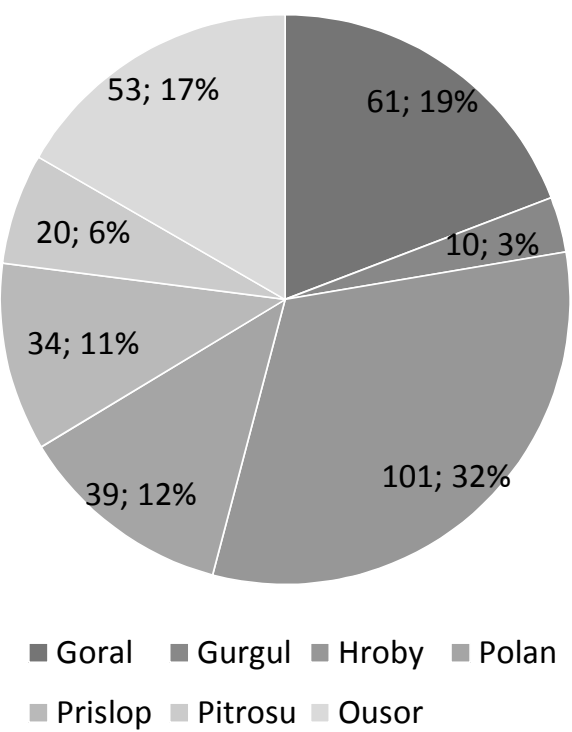


Figure 2: The offspring distribution of the reference stock per stud without immigration

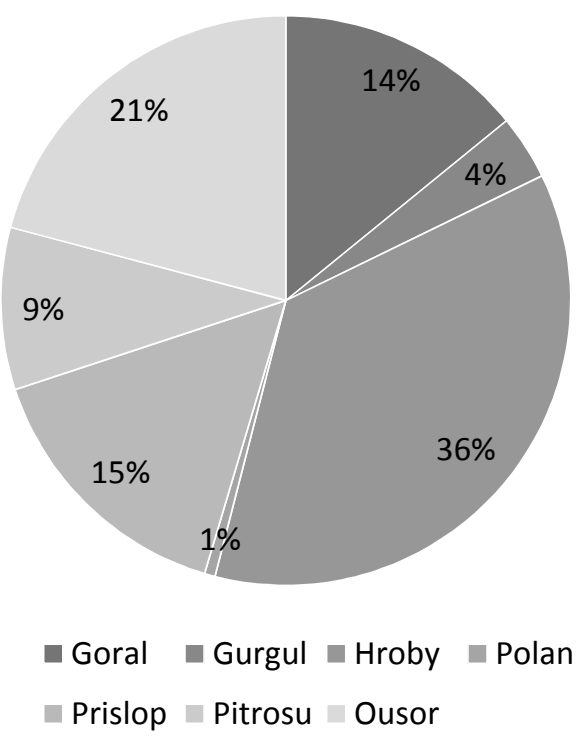

\section{Nei's genetic distance}

Figure 5 illustrates the Nei's genetic distance of the seven founder studs in the whole population, with and without the imported horses. The greatest distances are between the Polan and Prislop studs and the Polan and Pietrosu studs respectively. It is the individuals of the Goral and the Hroby studs that are closest to one another (Figure 5a). Through the import of 3139 Polan (Pol), the distance between the Polan and the other studs decreased. The distance between the Prislop and the Polan studs shortened to a greater extent than the distance between Prietrosu and Polan.

Figures 6-7 clearly reflect the change in the distance between the mare families as an effect of the imported animals. The genetic distance between the mare families 18 Barna and Zyrka is the greatest (Figure 6). There are very obvious genetic distances between the 18 Barna and Zyrka families and another 25 mare families. The former two mare families had their highest influence towards the end of the $20^{\text {th }}$ century; nowadays individuals from these families have been on the decrease and thereby the distance from the genetic composition of the other mare families has grown.

Figure 3: The offspring size distribution of the reference stock per mare family

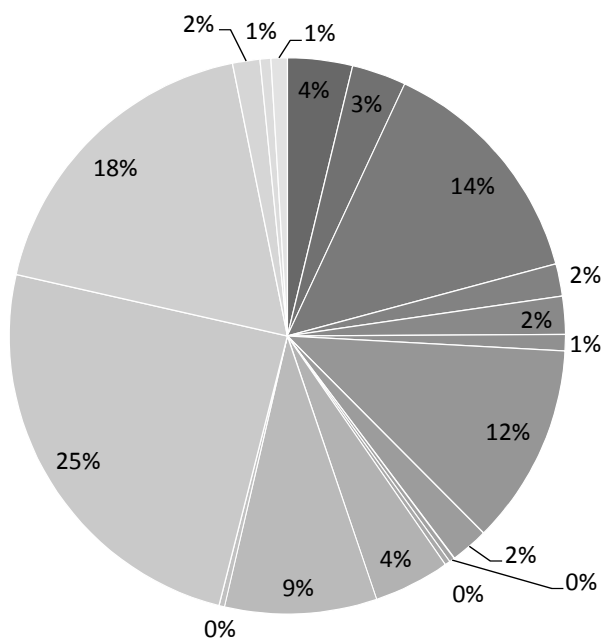
1 Panca
- 11 Rotunda
- 12 Sarata
17 Aglaia
- 2 Lucina
3 Tatarca
4 Kitca
5 Plosca
70 Sekacka
825 Agla
- 86 Deremoxa
882 Gelnica
90 Machocha
- Árvácska
Aspiráns
Bukovina
Wrona
Wydra

Figure 4: The offspring size distribution of the reference stock per mare family without the immigration

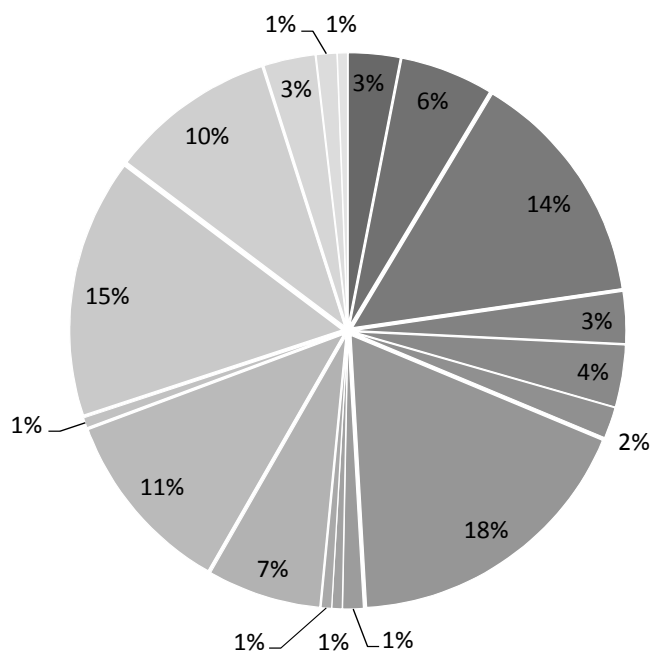

$$
\begin{aligned}
& \text { - } 1 \text { Panca } \\
& \text { - } 11 \text { Rotunda } \\
& \text { - } 12 \text { Sarata } \\
& 17 \text { Aglaia } \\
& \text { - } 2 \text { Lucina } \\
& \text { - } 3 \text { Tatarca } \\
& \text { - } 4 \text { Kitca } \\
& \text { - } 5 \text { Plosca } \\
& 70 \text { Sekacka } \\
& \text { 1 } 825 \text { Agla } \\
& 86 \text { Deremoxa } \\
& 882 \text { Gelnica } \\
& 90 \text { Machocha } \\
& \text { Árvácska } \\
& \text { Aspiráns } \\
& \text { Bukovina } \\
& \text { Wrona } \\
& \text { Wydra }
\end{aligned}
$$


Figure 5: Nei's genetic distance values in the 7 founding studs with (a) without (b) immigrant individuals

(a)

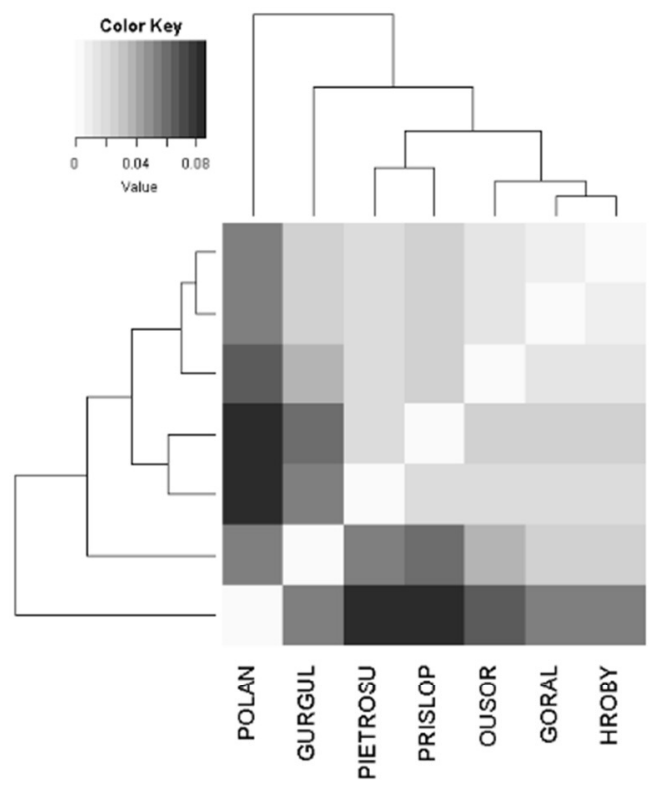

(b)

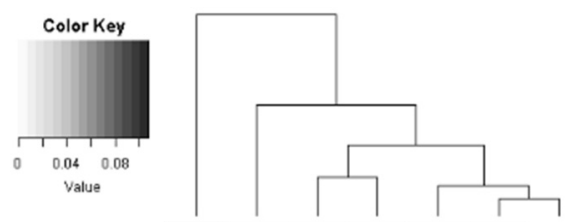

HROBY

GORAL

OUSOR

PRISLOP

PIETROSU

GURGUL

POLAN

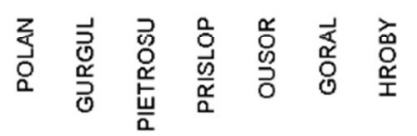

Figure 6: Nei's genetic distance values in mare families

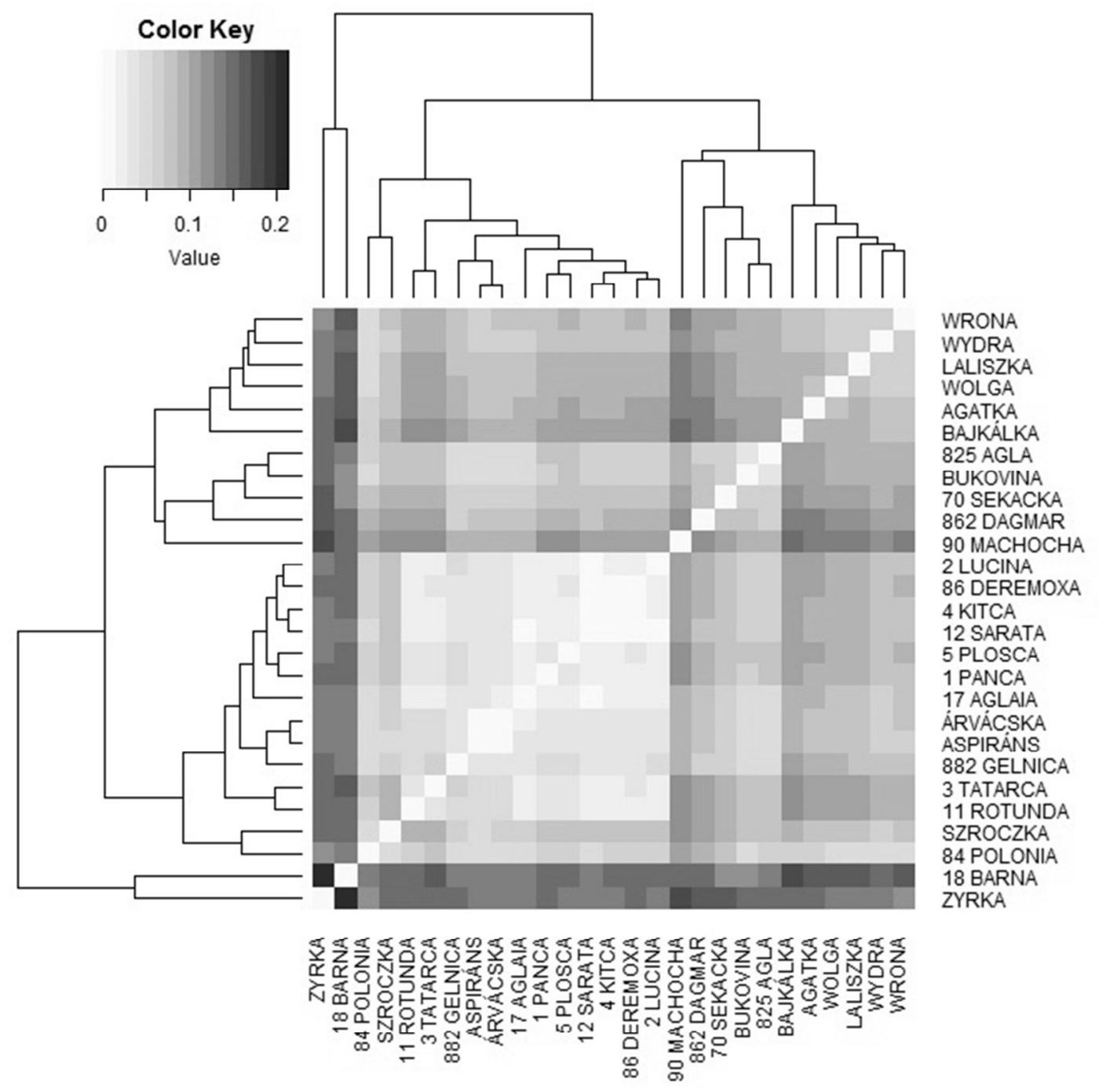


Figure 7: Nei's genetic distance values in mare families without immigrant individuals

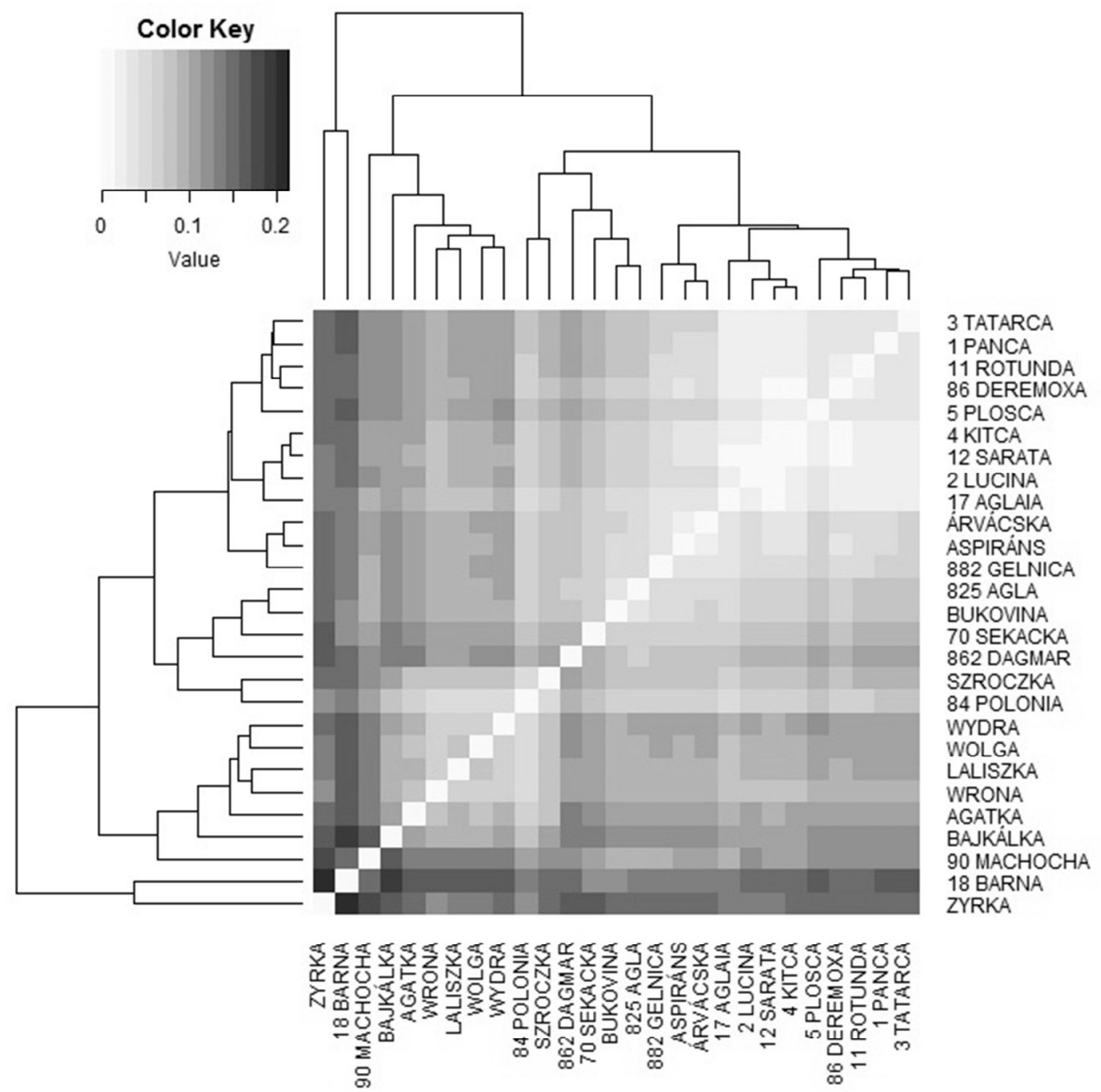

Immigration completely transformed by the fact that the immigration of the Polish horses had an insignificant effect on genetic distances. Figure 7 illustrates a bigger genetic distance between the mare family 90 Machocha and other mare families bred in the country. Interestingly, while immigration almost left the genetic distance of the mare families 18 Barna and Zyrka from the other mare families unchanged, it increased the genetic distance between the mare family 90 Machocha and the mare families Wydra, Wolga, Laliszka, Wrona, Agatka and Bajkálka. The genetic distance of the mare families 70 Seckacka and 862 Dagmar from the mare families Bajkálka and Agatka also became remarkable. All this favourably influences the genetic composition of the population and genetic diversity, helping to decide on practical pairing in later generations. As an effect of the seven individuals involved in the breeding, the genetic distance between the mare families 3 Tatarca, 11 Rotunda and the mare faimilies 86 Deremoxa, 5 Plosca and 1 Panca increased. The distance of the mare families 84 Polonia and Szroczka from the mare families 825 Agla, Bukovina, 70 Seckacka and 862 Dagmar grew. As an effect of the immigration, the genetic distance between the mare families Árvácska,
Aspiráns and the mare family 882 Gelnica got shorter, and the distance between the families 2 Lucina and 86 Deremoxa similarly decreased. Immigration completely transformed the Nei's genetic distance between respective mare families, its effect being generally beneficial for continuing successful breeding.

\section{CONCLUSIONS}

We examined the impact of involving seven Polish horses in the breeding through changes in the population genetic indicators of the reference stock of the Hungarian Hucul population of the year 2015. Our examination revealed that the individual among the Polish imported horses with the highest genetic impact was 3139 Polan (Pol). It was through it that the stud Polan got involved in the Hungarian breeding, whereby the Nei's distances between Polan and the other 6 studs shortened, too. The Nei's genetic distances between the mare families also changed as an effect of the imported horses. In general, genetic distances between the mare families increased; on the other hand it continued to decrease between the mare families Aspiráns and Árvácska established from the 1960's and exclusively 
representing the breed. Through the import of individuals that can be considered to have rare pedigrees in Hungary, the representatives of missing stallion studs and mare families have been added to the population and, through the increased genetic variability, made it safer to sustain the breed in Hungary.

\section{REFERENCES}

Bartolomé, E.-Cervantes, I.-Valera, M.-Gutiérrez, J. P. (2011): Influence of foreign breeds on the genetic structure of the Spanish Sport Horse population. Livestock Science. 142: 70-79.

Gutiérrez, J. P.-Goyache, F. (2005): A note on ENDOG: a computer program for analysing pedigree information. Journal of Animal Breeding and Genetics. 122: 172-176.

Khanshour, A.-Conant, E.-Juras, R.-Cothran, E. G. (2013): Microsatellite Analysis of Genetic Diversity and Population Structure of Arabian Horse Populations. Journal of Heredity. 104. 3: 386-398.

Koenena, E. P. C.-Aldridgeb, L. I.-Philipssonc, J. (2004): An overview of breeding objectives for warmblood sport horses. Livestock Production Science. 88: 77-84.

Lámfalusy K. N. (2012): A szilvásváradi lipicai ménes 14 import ménjének és 46 ivadékának a beltenyésztési vizsgálata. Szakdolgozat. Debreceni Egyetem. Debrecen.
Marletta, D.-Tupac-Yupanqui, I.-Bordonaro, G.-Guastella, A. M.Criscione, A.-Canon, J.-Dunner, S. (2006): Analysis of genetic diversity and the determination of relationships among western Mediterranean horse breeds using microsatellite markers. Journal of Animal Breeding and Genetics. 123: 315-325.

Nei, M. (1987): Molecular Evolutionary Genetics. Columbia University Press. New York. 512.

Plante, Y.-Vega-Pla, J. L.-Lucas, Z.-Colling, D.-De March, B.Buchanan, F. (2007): Genetic Diversity in a Feral Horse Population from Sable Island, Canada. Journal of Heredity. 98. 6: 594-602.

Vostrá-Vydrová, H.-Vostrý, L.-Hofmanová, B.-Krupa, E.Zavadilová, L. (2016): Pedigree analysis of the endangered Old Kladruber horse population. Livestock Science. 185: 17-23.

Zabek, T.-Nogaj, A.-Radko, A.-Nogaj, J.-Slota, E. (2005): Genetic variation of Polish endangered Bilgoraj horses and two common horse breeds in microsatellite loci. Journal of Applied Genetics. 46. 3: 299-305. 